\title{
Ultrastructure of Sclerotia and Hyphae of Sclerotium rolfsii Sacc.
}

\author{
I. CHET, Y. HENIS AND NAOMI KISLEV \\ The Hebrew University of Jerusalem, Faculty of Agriculture, \\ Rehovot, Israel
}

(Accepted for publication 22 March 1969)

\section{SUMMAR Y}

The ultrastructure of cells of the sclerotia and aerial mycelium of Sclerotium rolfsii Sacc. was studied by electron microscopy. A mature sclerotium of $S$. rolfsii contains several types of differentiated cells. The thick-walled rind cells which comprise the sclerotial envelope are empty. The underlying cortex cells have thinner walls and contain many vesicles full of reserve materials which appear dark after treatment with osmium tetroxide. Although less reactive to osmium tetroxide, the cells between the cortex and medulla are also rich in reserve materials, some of which are membrane-bound. The inner layer (medulla) is composed of cells with extremely thick walls, of thinner-walled cells full of reserve materials and of empty cells. The walls of the hyphal cells are significantly thinner, and less optically dense than the walls of any of the sclerotial cells. Hyphal cells contain more ribosomes and mitochondria than sclerotial cells.

It seems that the resistance of sclerotia to biological degradation depends upon the melanin-rich rind as well as the wall structure and organization of cells comprising the inner layers of the sclerotium.

\section{INTRODUCTION}

Some septate fungi are capable of forming sclerotia, which consist of firm aggregates of vegetative hyphae and serve as a means of survival for these fungi, being very resistant to biological degradation (Butler, 1966).

According to Townsend \& Willetts (1954), who investigated the development and the structure of several types of sclerotia by the light microscope, a mature sclerotium of Sclerotium rolfsii Sacc. is composed of four distinct cell layers: (a) a fairly thick skin, (b) a rind, two to four cells thick, made of broad and tangentially flattened cells, $(c)$ a cortex of thin-walled cells with densely staining cytoplasm and (d) a medulla made of loosely arranged, ordinary filamentous hyphae, also filled with dense contents. So far, no information is available about the morphology and function of individual cells comprising these layers. The present study was begun in an attempt to reveal the organization and ultrastructure of the sclerotial cells; as compared with hyphal cells of $S$. rolfsii.

\section{METHODS}

The fungus Sclerotium rolfsii Sacc. was isolated from infected sugar beet. It was grown in Petri dishes, each containing $20 \mathrm{ml}$. of defined medium (Chet, Henis \& Mitchell, 1967) prepared according to Joham (1943). The inoculated agar plates were incubated at $30^{\circ}$. 
Samples of aerial mycelium were taken from the centre of a 3-week-old colony ('old' mycelium) and from the margins of a 5-day-old colony ('young' mycelium).

Thin sections for electron microscopy were prepared from brown, mature sclerotia or aerial hyphae. These were dipped in tubes, each containing I $\mathrm{ml}$. cooled $5 \%$ glutaraldehyde in $0.1 \mathrm{M}$-phosphate buffer $(\mathrm{pH} 7 \cdot 0$ ) for I hr. After three rinsings with cold buffer the material was fixed with cold $2 \% \mathrm{OsO}_{4}$ in the same buffer for $22 \mathrm{hr}$ (sclerotia) or for $2 \mathrm{hr}$ (hyphae). After dehydration with ethanol the material was embedded in Epon 8I2. Thin sections were prepared with an LKB Ultrotome III, using glass knives. The sections were stained with $3 \%$ uranyl acetate for I hr with 'Karnovsky's Method A' lead hydroxide (Pease, I964), for $20 \mathrm{~min}$. and examined with a JEM-T7 electron microscope, and with a Zeiss GFL phase-contrast microscope.

\section{RESULTS}

\section{Sclerotia}

A phase contrast micrograph of a section of a mature sclerotium is seen in Pl. I, fig. I. The layers described by Townsend $\&$ Willetts (1954) are clearly seen. The rind (a) was composed of thick-walled, empty cells. The cortex cells (b) appeared very dark, possibly as a result of a reaction of their polymetaphosphates or lipids with $\mathrm{OsO}_{4}$ (Bracker, 1967; Edwards \& Edwards, 1960; Scurti \& Converso, 1965). In addition, an intermediate layer $\left(b_{1}\right)$, containing cells with brightly granulated cytoplasm was seen between the cortex and the medulla (c).

In electron micrographs of sections of sclerotia, the walls of all sclerotial cells (Pl. I , fig. 2 to 6; Pl. 2, fig. 7 and 8) appeared thicker than those of the hyphae (Pl. 2, fig. 9 to 14). Cell wall residues, apparently comprising a part of the sclerotial skin (Townsend \& Willetts, 1954), were attached to the melanin-rich, thick-walled rind cells (Bloomfield \& Alexander, 1967) which appeared empty (Pl. 1, fig. 2). The cortex cells (Pl. I, fig. 3) were very big and were full of huge vesicles, leaving only a little space for the cytoplasm and other cell organelles.

The cells of the intermediate layer (Pl. I, fig. I, $b_{1}$ were of special interest. Their walls were thicker than those of the cortex cells, their cytoplasm was full of electrondense granules (Pl. I, fig. 4 and 5, g) typical of polysaccharides (Bracker, 1967) and of membrane-bound electron-dense bodies (d) similar to those described by Gay \& Greenwood (1966).

In contrast to the above layers, the cells comprising the medulla (PI. I, fig. I c; fig. 5) were loosely arranged and extremely heterogeneous, showing empty thin-walled cells (Pl. I, fig. 5, arrow) and extremely thick-walled cells (Pl. I, fig. 5 and 6; PI. 2, fig. 7) resembling 'fibre hyphae' found in rhizomorphs of Armillaria mellea and Trametes quercina by Schmidt \& Liese (I968), as well as cell types similar to those found in the intermediate layer of the cortex. Dolipore septa characteristic of basidiomycetes (Bracker, 1967) were also observed (Pl. I, fig. 5; Pl. 2, fig. 8).

\section{Hyphae}

In both 'young' (Pl. 2, fig. 9 to I I) and 'old' (Pl. 2, fig. I2 to I4) cell types the wall was much thinner than that of any sclerotial cell. In contrast to the sclerotial cell walls, the fibrillar structure of the hyphal walls was clearly seen (Pl. 2, fig. 12 and I4). The hyphal wall thickness varied from $0 . \mathrm{I} \mu$ at the tips to $0.3 \mu$. In both 'old' and 
'young' hyphae, cytoplasmic membrane was significantly folded in the hyphal tips (Pl. 2, fig. 9 and 10). In addition, small vesicles or tubules closely associated with the cytoplasmic membrane were observed in most sections. These structures were not observed in the sclerotial cells. They seemed to be enclosed between the cytoplasmic membrane and the cell wall (Pl. 2, fig. I I to I4).

Dark bodies, possibly polysaccharides (Bracker, 1967), appeared especially in the vicinity of hyphal tip initiation (Pl. 2, fig. 9 and $\mathrm{IO}$ ). In general, hyphal cells were much richer in ribosomes and mitochondria than sclerotial cells, indicating a lower metabolic activity of the sclerotial cells.

\section{DISCUSSION}

The results presented here confirm that the sclerotium of Sclerotium rolfsii is a complex body, containing differentiated and possibly specialized cell types (Aycock, 1966). The description of the ultrastructure of the cortex and the medulla of sclerotia of $S$. rolfsii differs from that reported by Townsend \& Willetts (I954), who assumed that both layers consisted of ordinary hyphal mycelium.

The structure of the hyphal cells of Sclerotium rolfsii as observed under the electron microscope is very similar to that described by Icochea (1966), who used phase microscopy and staining procedures. In addition to the usual subcellular organelles and reserve materials, hyphal cells often contain small vesicles attached to the cytoplasmic membrane, resembling 'lomasomes', considered by some authors as playing a role in cell wall synthesis (Bracker, 1967), or 'multivesicular bodies' found by Calonge, Fielding \& Byrde (1969) in Scelorinia fructigena, possibly playing a role in enzyme secretion.

It is of interest to compare the structure of sclerotia of Sclerotium rolfsii to those of other fungi. The structure of microsclerotia of Verticillium albo-atrum was investigated by Nadakavukaren (1963), who found that microsclerotial units were composed of thin- and thick-walled cells in close association with each other. The large thick-walled cells contained different cytoplasmic inclusions and food vacuoles, whereas the thinwalled cells contained nuclei or were empty. The thick-walled cells appeared to serve both as a protection and as a nutrient source for the thin-walled ones.

Scurti \& Converso (1965), who studied the ultrastructure of sclerotia produced by a Typhula sp., noted the presence of two cell types: $(a)$ cells with high metabolic activity; $(b)$ cells rich in stored food material. Cytoplasm of the first type was abundant and homogeneous, containing mitochondria and endoplasmic reticulum. Cells of the second type had thicker walls and their nuclei and mitochondria were hidden beneath the stored food material, which consisted of polymetaphosphates, polysaccharides and fats.

The findings presented in this study support the earlier suggestions that melanin alone does not account for the higher resistance to lytic enzymes of sclerotial as compared to hyphal walls (Chet \& Henis, 1967, 1969).

It seems that the studies hitherto made on the chemical composition of sclerotial walls either represent the sclerotial skin rather than the outer rind as claimed by Bloomfield \& Alexander (1967), or an average value of the walls of aggregates of different cell types, mainly from the cortex and the rind (Chet et al. 1967), whose separation seems impossible at present. Therefore, the interesting problem of the 
specific role of the various cell types in sclerotial persistence and germination awaits further investigation.

This work was partially supported by Grant no. FG-Is-I6o from the U.S. Department of Agriculture.

\section{REFERENCES}

Aycock, R. (1966). Stem rot and other diseases caused by Sclerotium rolfsii. Tech. Bull. no. 174, N. Carol. agric. Exp. Stn. N.C. State University at Raleigh, N.C.

Bloomfield, B. J. \& Alexander, M. (1967). Melanins and resistance of fungi to lysis. J. Bact. 93, 1276.

Bracker, C. E. (1967). Ultrastructure of fungi. A. Rev. Phytopath. 5, 343.

Butler, G. M. (1966). Vegetative structures. In The Fungi. Ed. by G. C. Ainsworth and A. S. Sussman, vol. 2, p. 83. New York and London: Academic Press.

Calonge, F. D., Fielding, A. H. \& Byrde, R. J. W. (1969). Multivesicular bodies in Sclerotinia fructigena and their possible relation to extracellular enzyme secretion. J. gen. Microbiol. 55 , 177.

Chet, I. \& Henss, Y. (1967). Hyphal and sclerotial walls of Sclerotium rolfsii: Chemical composition and dissolution by lytic enzymes. The First Israel Congress of Plant Pathology, p. $3 \mathrm{I}$.

Chet, I. \& Henis, Y. (1969). Effect of catechol and disodium-EDTA on melanin content of hyphal and sclerotial walls of Sclerotium rolfsii Sacc. and the role of melanin in the susceptibility of these walls to $\beta-(\mathrm{I} \rightarrow 3)$ glucanase and chitinase. Soil Biol. \& Biochem. I (in the Press).

Chet, I., Henis, Y. \& MrTChell, R. (1967). Chemical composition of hyphal and sclerotial walls of Sclerotium rolfsii Sacc. Can. J. Microbiol. r3, 37.

EDWARDS, G. A. \& EDWARDS, M. R. (1960). The intracellular membranes of Blastomyces dermatitidis. Am. J. Bot. 47, 622.

GaY, J. L. \& GreENwoOd, A. D. (1966). Structural aspects of zoospore production in Saprolegnia ferax with particular reference to the cell and vacuolar membranes. In The Fungus Spore, Proceedings of the 18th Symposium of the Colston Research Society, Bristol p. 95.

ICOCHEA, T. (1966). Comparative studies with Sclerotium coffeicolum and S. rolfsii. Ph.D. Dissertation North Carolina State University. Cited by R. Aycock, in Stem rot and other diseases caused by S. rolfsii. Tech. Bull. no. 174, N. Carol. agric. Exp. Stn, Raleigh, N.C.

JoHAм, H. E. (1943). A nutritional study of the fungus Sclerotium rolfsii. M.Sc. thesis. The Texas Agricultural and Mechanical University.

NADAKavuKaren, M. J. (1963). Fine structure of microsclerotia of Verticillium albo-atrum, Reinke \& Berth. Can. J. Microbiol. 9, $4 \mathrm{II}$.

Pease, D. C. (1964). Histological Techniques for Electron Microscopy. New York: Academic Press.

SCHMmT, R. \& LIESE, W. (1968). Structural and histochemical observations on fungal fibre hyphae. In Electron Microscopy, 1968. Ed. by D. S. Bocciarelli, vol. 2, p. 415. Roma: Tipografia Poliglotta Vaticana.

SCuRTI, J. C. \& CONVERSo, L. (1965). Sulla struttura microscopica e ultromicroscopica degli sclerozi di Typhula sp. Caryologia 18, 263.

Townsend, B. B. \& Willetrs, H. J. (1954). The development of sclerotia of certain fungi. Trans. Br. mycol. Soc. 37, 213.

\section{EXPLANATION OF PLATES}

\section{Plate I}

Fig. I. A thin section of a mature sclerotium fixed with osmium tetroxide, showing rind (a), dark cortex (b), intermediate layer consisting of cells with brightly granulated cytoplasm $\left(b_{1}\right)$ and medulla (c). Phase contrast $(\times 1000)$.

Fig. 2. Ultrathin section of the outer layer of a mature sclerotium showing skin (arrows) and empty rind cells with thick walls $(w)(\times 7500)$.

Fig. 3. Ultrathin section showing parts of some cortex cells, with thick walls (w) and huge vesicles (v) full of fine, dark granules $(\times 7500)$. 
Journal of General Microbiology, Vol. 57, No. 2

Plate I
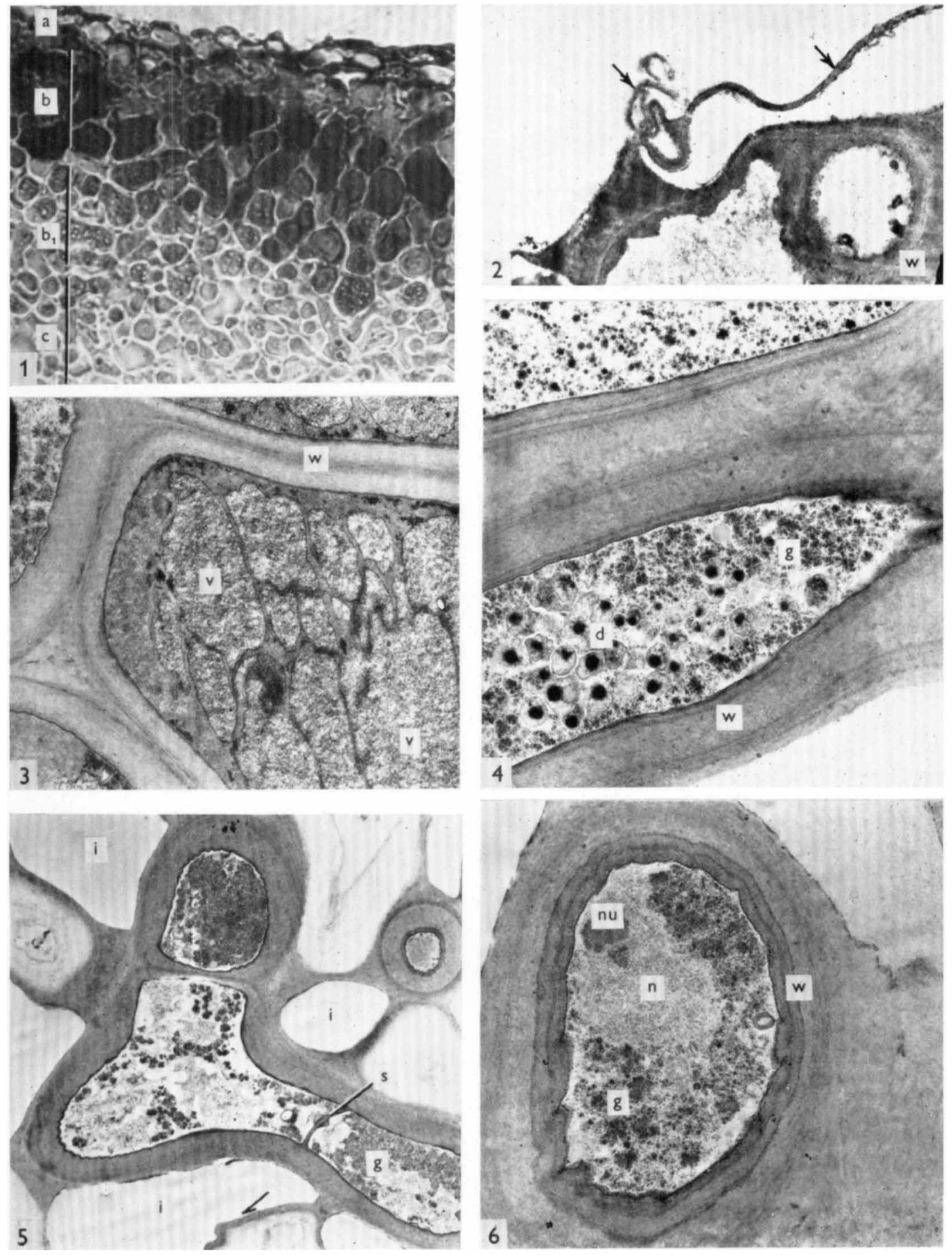
Journal of General Microbiology, Vol. 57, No. 2

Plate 2
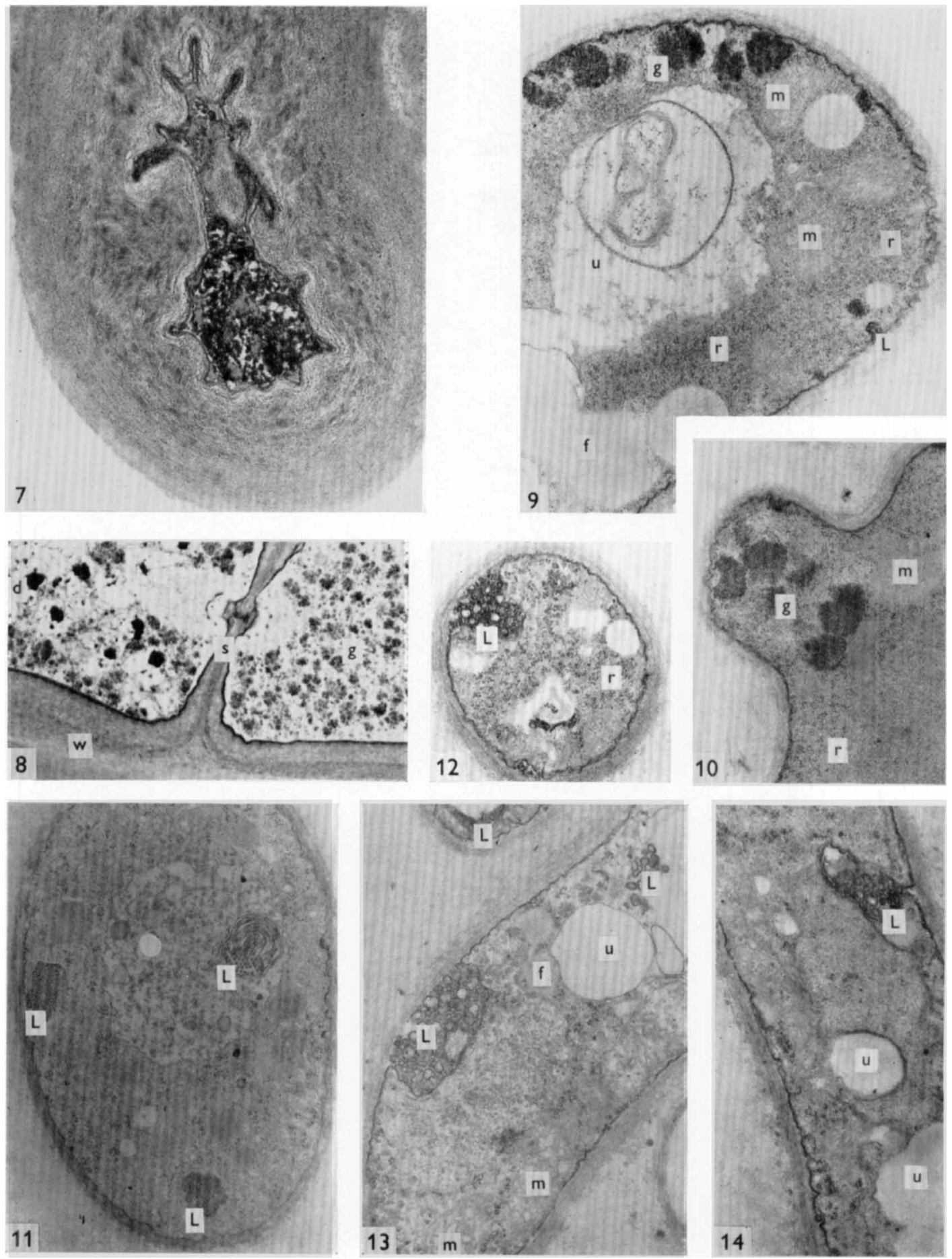

I. CHET, Y. HENIS ANI N. KISLEV 
Fig. 4. A part of a cell from the intermediate layer $\left(b_{1}\right)$ (Fig. 2$)$ showing thick wall $(w)$, polysaccharide granules (g) and membrane-bound electron dense bodies (d) $(\times 7500)$.

Fig. 5. Ultrathin section of medullar cells, showing cells with thick wall (w), full of polysaccharide granules (g), empty cells with thin walls (arrows), a dolipore septum (s) connecting separate cells and intracellular spaces (i) $(\times 3400)$.

Fig. 6. Ultrathin section of a thick-walled medullar cell, showing a thick wall (w) consisting of several layers, polysaccharide granules (g), nucleus (n) and nucleolus (nu) $(\times 7500)$.

\section{Plate 2}

Fig. 7. A medullar cell with extremely thick wall and degenerated cytoplasm $(\times 12500)$.

Fig. 8. Ultrathin section of two adjacent medullar cells showing thick walls (w), dolipore septum (s), polysaccharide granules $(\mathrm{g})$ and membrane-bound, electron-dense bodies $(\mathrm{d})(\times 7500)$.

Fig. 9. Ultrathin section of a hyphal tip of a 'young' aerial mycelium, showing thin wall and folded cytoplasmic membrane, polysaccharide granules (g), mitochondria (m), 'lomasomes' (L), fat bodies (f) and a vacuole (u). Note the abundance of ribosomes $(r)(\times 15000)$.

Fig. 10. A branching initiation at the distal part of the same hyphal tip shown in Fig. 9. Note the concentration of polysaccharide granules $(g)$ at the growing tip. Symbols as in Fig. 9. $(\times 15000)$.

Fig. I I. Ultrathin transverse section of a 'young ' hyphal cell, showing groups of tubular 'lomasomes' (L), some being cut longitudinally and some transversely. One group is observed between the cell wall and the cytoplasmic membranes; others appearing as situated inside the cell, probably protruding from the cell boundary (see also Fig. 14) ( $\times 15000)$.

Fig. 12. Ultrathin section of 'old' hyphal cells, showing 'lomasomes' (L) and ribosomes (r) ( $\times$ I 5000).

Fig. 13 and 14. Longitudinal section of tip (Fig. 13) and distal (Fig. 14) parts of 'old' hyphal cells, showing mitochondria $(\mathrm{m})$, fat bodies $(\mathrm{f})$, 'lomasomes' $(\mathrm{L})$ and vacuole $(\mathrm{u})(\times$ I 5000$)$. 